\title{
Heterotrophic Nitrification-Aerobic Denitrification Performance of Strain Y-12 under Low Temperature and High Concentration of Inorganic Nitrogen Conditions
}

\author{
Qing Ye ${ }^{1}$, Kaili $\mathrm{Li}^{2}$, Zhenlun $\mathrm{Li}^{1, *}, \mathrm{Yi} \mathrm{Xu}^{1}{ }^{1}$, Tengxia He ${ }^{1}$, Wenhao Tang ${ }^{1}$ and Shudi Xiang ${ }^{1}$ \\ 1 Chongqing Key Laboratory of Soil Multiscale Interfacial Progress, College of Resource and Environments, \\ Southwest University, Chongqing 400716, China; yq1992xd@email.swu.edu.cn (Q.Y.); \\ xy1992xd@163.com (Y.X.); hetengxia5153@163.com (T.H.); tangwh0520@sina.com (W.T.); \\ xiangshudishudi@sina.com (S.X.) \\ 2 School of Chemical Engineering, University of Queensland, Brisbane, Queensland 4072, Australia; \\ star03344@sina.com \\ * Correspondence: lizhlun4740@sina.com
}

Received: 12 September 2017; Accepted: 27 October 2017; Published: 30 October 2017

\begin{abstract}
An aerobic nitrite-denitrifying bacterium Pseudomonas putida Y-12 was used to remove sole and mixed nitrogen sources at $15{ }^{\circ} \mathrm{C}$. When strain $\mathrm{Y}-12$ was incubated for 4 days with a sole nitrogen source and initial $\mathrm{NH}_{4}{ }^{+}-\mathrm{N}, \mathrm{NO}_{3}{ }^{-}-\mathrm{N}$, and $\mathrm{NO}_{2}{ }^{-}-\mathrm{N}$ concentrations of 208.1, 204.7, and $199.0 \mathrm{mg} / \mathrm{L}$, respectively, the removal ratios of $\mathrm{NH}_{4}{ }^{+}-\mathrm{N}, \mathrm{NO}_{3}{ }^{-}-\mathrm{N}$, and $\mathrm{NO}_{2}{ }^{-}-\mathrm{N}$ were 98.8, 73.6, and $77.1 \%$, respectively. The average removal rates of $\mathrm{NH}_{4}{ }^{+}-\mathrm{N}, \mathrm{NO}_{3}{ }^{-}-\mathrm{N}$, and $\mathrm{NO}_{2}{ }^{-}{ }^{-} \mathrm{N}$ reached $2.14,1.57$, and $1.60 \mathrm{mg} / \mathrm{L} / \mathrm{h}$, respectively. Intermediate products $\left(\mathrm{NO}_{3}{ }^{-}-\mathrm{N}\right.$ and $\left.\mathrm{NO}_{2}{ }^{-}-\mathrm{N}\right)$ were detected at a low level. Total nitrogen removal was mainly achieved during the stationary phase in the denitrification process. All the results indicated that strain Y-12 could perform heterotrophic nitrification and aerobic denitrification at $15{ }^{\circ} \mathrm{C}$, which was beneficial for future applications in wastewater treatment at low temperatures.
\end{abstract}

Keywords: psychrotolerant; nitrite-denitrifying; pseudomonas putida; simultaneous heterotrophic nitrification and denitrification; wastewater treatment

\section{Introduction}

Human activities, such as excessive use of artificial fertilizer, excessive throwing of fish feed, and improper discharge of livestock waste or industrial effluents, lead to nitrogen accumulation in water environments [1,2]. Moreover, excessive nitrogen in water bodies may do harm to both aquatic life and human beings. For instance, $\mathrm{NH}_{4}{ }^{+} \mathrm{N}$ damages the liver and kidney of fishes, $\mathrm{NO}_{3}{ }^{-}-\mathrm{N}$ destroys the immune system of fishes, and $\mathrm{NO}_{2}{ }^{-}-\mathrm{N}$ can cause severe health problems such as methemoglobinemia in infants and even cancer in humans [3-5]. Therefore, finding a method to remove the undesirable nitrogen is essential and urgent. From the previous reports, biological methods, which have the advantages of low-cost, high efficiency, and good sustainability, have been widely used in city sewage treatment [6]. However, the traditional method of biological nitrogen removal requires two separate systems: autotrophic nitrification $\left(\mathrm{NH}_{4}{ }^{+} \rightarrow \mathrm{NH}_{2} \mathrm{OH} \rightarrow \mathrm{NO}_{2}{ }^{-} \rightarrow \mathrm{NO}_{3}{ }^{-}\right)$under aerobic conditions and heterotrophic denitrification $\left(\mathrm{NO}_{3}{ }^{-} \rightarrow \mathrm{NO}_{2}{ }^{-} \rightarrow \mathrm{NO} \rightarrow \mathrm{N}_{2} \mathrm{O} \rightarrow \mathrm{N}_{2}\right)$ under anoxic conditions $[7,8]$, making it relatively more expensive. To date, more and more bacteria with abilities of heterotrophic nitrification and aerobic denitrification (HN-AD) have been reported since Roberson firstly separated the aerobic denitrifier [9-12]. These bacteria could not only realize nitrification and denitrification occurring in one aerobic system, but also balance the alkalinity produced via 
denitrification $[9,13]$. Thus, bacteria with HN-AD ability under aerobic conditions have shown more potential application prospects in the wastewater treatment field.

Nevertheless, studies on these bacteria with HN-AD ability have mainly been targeted at removing a sole nitrogen source, and most of these bacteria were related to $\mathrm{NH}_{4}{ }^{+}-\mathrm{N}$ or $\mathrm{NO}_{3}{ }^{-}-\mathrm{N}$ removal but seldom involve $\mathrm{NO}_{2}{ }^{-}-\mathrm{N}$ removal $[12,13]$. Also, some bacteria could not remove $\mathrm{NO}_{3}{ }^{-}-\mathrm{N}$ or $\mathrm{NO}_{2}{ }^{-}-\mathrm{N}$, even with efficient $\mathrm{NH}_{4}{ }^{+}-\mathrm{N}$ removal ability $[12,14,15]$. Although some bacteria could remove $\mathrm{NH}_{4}{ }^{+}-\mathrm{N}$ and $\mathrm{NO}_{3}{ }^{-}-\mathrm{N}\left(\right.$ or $\left.\mathrm{NO}_{2}{ }^{-}-\mathrm{N}\right)$, respectively [16,17], few bacteria could remove $\mathrm{NH}_{4}{ }^{+}-\mathrm{N}$ and $\mathrm{NO}_{3}{ }^{-}-\mathrm{N}$ (or $\mathrm{NO}_{2}{ }^{-}-\mathrm{N}$ ) simultaneously [18]. In addition, environmental factors, such as high-concentration substrates and low temperature, could inhibit the cell growth and influence the removal efficiency [14,19-21]. Therefore, screening and studying more efficient microbes, which were capable of removing sole and mixed nitrogen sources under conditions of low temperature and high-concentration substrates, have become an important task in the technology of biological denitrification.

Our group had isolated an aerobic nitrite-denitrifying bacterium named Pseudomonas putida Y-12 from winter paddy fields, which exhibited fast and efficient removal of low-concentration nitrite and total nitrogen (TN) at $15^{\circ} \mathrm{C}$ [22]. However, there was little knowledge about the removal performance of other nitrogen sources. In this study, the cell growth and nitrogen removal performance of strain Y-12 under different forms of high-loading nitrogen sources, such as $\mathrm{NH}_{4}{ }^{+}-\mathrm{N}, \mathrm{NO}_{3}{ }^{-}-\mathrm{N}, \mathrm{NO}_{2}{ }^{-}-\mathrm{N}$, and mixed nitrogen sources, were investigated and evaluated at $15{ }^{\circ} \mathrm{C}$. Strain $\mathrm{Y}-12$ showed great abilities to remove $\mathrm{NH}_{4}{ }^{+}-\mathrm{N}, \mathrm{NO}_{3}{ }^{-}-\mathrm{N}$, and $\mathrm{NO}_{2}{ }^{-}-\mathrm{N}$ separately, and exhibited the capacity to remove $\mathrm{NH}_{4}{ }^{+}-\mathrm{N}$ mixed with $\mathrm{NO}_{3}{ }^{-}-\mathrm{N}$ (or $\mathrm{NO}_{2}{ }^{-}-\mathrm{N}$ ) simultaneously at $15{ }^{\circ} \mathrm{C}$. All the results can contribute to the actual application of strain $\mathrm{Y}-12$ in wastewater treatment at low temperatures.

\section{Materials and Methods}

\subsection{Strain Used}

Strain Y-12 was isolated from long-term flooded paddy soil [22] and stored in 25\% glycerin solution at $-80^{\circ} \mathrm{C}$. Strain $\mathrm{Y}-12$ was pre-incubated in a $250-\mathrm{mL}$ conical flask containing $100 \mathrm{~mL}$ Luria-Bertani (LB) medium at $15^{\circ} \mathrm{C}$ and $150 \mathrm{rpm}$ for about $36 \mathrm{~h}$. Each seed solution of bacterial suspension used in the following experiments was obtained by centrifuging ( $4000 \mathrm{rpm}, 5 \mathrm{~min}) 8 \mathrm{~mL}$ of pre-incubated strain Y-12 and washing once with sterilized pure water.

\subsection{Medium Used}

Luria-Bertani (LB) medium contained $10 \mathrm{~g} / \mathrm{L}$ of tryptone, $5 \mathrm{~g} / \mathrm{L}$ of yeast extract, and $10 \mathrm{~g} / \mathrm{L}$ of $\mathrm{NaCl}$.

Inorganic nitrogen medium included nitrification medium (NM) [23], denitrification medium (DM-1 and DM-2), and simultaneous nitrification and denitrification medium (SND-1 and SDN-2); the components of each medium are shown in Table 1.

Table 1. The ingredients of inorganic medium in $1 \mathrm{~L}$ ultrapure water.

\begin{tabular}{|c|c|c|c|c|c|c|c|c|}
\hline \multirow{2}{*}{ Medium } & $\mathrm{K}_{2} \mathrm{HPO}_{4}$ & $\mathrm{KH}_{2} \mathrm{PO}_{4}$ & $\mathrm{MgSO}_{4} \cdot 7 \mathrm{H}_{2} \mathrm{O}$ & $\mathrm{FeSO}_{4} \cdot 7 \mathrm{H}_{2} \mathrm{O}$ & $\mathrm{CH}_{3} \mathrm{COONa}$ & $\left(\mathrm{NH}_{4}\right)_{2} \mathrm{SO}_{4}$ & $\mathrm{KNO}_{3}$ & $\mathrm{NaNO}_{2}$ \\
\hline & (g) & (g) & (g) & (g) & (g) & (g) & (g) & (g) \\
\hline $\mathrm{NM}^{*}$ & 7.0 & 3.0 & 0.1 & 0.05 & 10 & 0.95 & - & - \\
\hline DM-1* & 7.0 & 3.0 & 0.1 & 0.05 & 10 & - & 1.5 & - \\
\hline DM-2 & 7.0 & 3.0 & 0.1 & 0.05 & 10 & - & - & 0.99 \\
\hline SND-1 * & 7.0 & 3.0 & 0.1 & 0.05 & 10 & 0.95 & 1.5 & - \\
\hline SND-2 & 7.0 & 3.0 & 0.1 & 0.05 & 10 & 0.95 & - & 0.99 \\
\hline
\end{tabular}

Note: ${ }^{*} \mathrm{NM}, \mathrm{DM}$ and SND mean the nitrificaiton medium, denitrification medium and simultaneous nitrification and denitrificaion medium, respectively. 
Each 250-mL conical flask containing $100 \mathrm{~mL}$ medium with an initial $\mathrm{pH}$ of 7.2 was autoclaved for $30 \mathrm{~min}$ at $121^{\circ} \mathrm{C}$.

\subsection{Nitrogen Removal Capacity and Conversion Relationship of Strain $Y-12$}

Each seed solution of strain Y-12 was inoculated into the conical flask containing $100 \mathrm{~mL}$ NM, DM-1, DM-2, OM, SND-1, or SND-2 medium, respectively. Each culture medium was incubated at $150 \mathrm{rpm}$ and $15^{\circ} \mathrm{C}$ for 4 days and sampled periodically for analysis every $24 \mathrm{~h}$. All experiments were conducted in triplicate. Different medium samples were directly used to measure the concentrations of total nitrogen (TN) and cell density. Subsequently, after centrifuging the medium samples at $8000 \mathrm{rpm}$ for $10 \mathrm{~min}$, the supernatant was used to analyze the concentrations of $\mathrm{NH}_{4}{ }^{+}-\mathrm{N}, \mathrm{NO}_{3}{ }^{-}-\mathrm{N}, \mathrm{NO}_{2}{ }^{-} \mathrm{N}$, and $\mathrm{NH}_{2} \mathrm{OH}-\mathrm{N}$, and the precipitate was washed with ultrapure water (twice) and used for microbial biomass nitrogen determination. The removal ratio of $\mathrm{NH}_{4}{ }^{+}-\mathrm{N}\left(\mathrm{NO}_{3}{ }^{-}-\mathrm{N}, \mathrm{NO}_{2}{ }^{-}-\mathrm{N}\right.$, or $\left.\mathrm{TN}\right)$ was calculated by the equation: $R v=\left(T_{2}-T_{1}\right) / T_{1} \times 100 \%$ to assess the nitrification and denitrification ability of strain $\mathrm{Y}-12$. $R v, T_{1}$, and $T_{2}$ express the removal ratio, initial concentration, and final concentration of $\mathrm{NH}_{4}{ }^{+}-\mathrm{N}\left(\mathrm{NO}_{3}{ }^{-}-\mathrm{N}, \mathrm{NO}_{2}{ }^{-}-\mathrm{N}\right.$, or TN), respectively. The nitrification (denitrification) rate of $\mathrm{NH}_{4}{ }^{+}-\mathrm{N}\left(\mathrm{NO}_{3}{ }^{-}-\mathrm{N}\right.$ or $\left.\mathrm{NO}_{2}{ }^{-}-\mathrm{N}\right)$ was calculated by the equation: $S=\left(T_{4}-T_{3}\right) / t . S, t, T_{4}$, and $T_{3}$ express the nitrificaiton (denitrification) ratio, the reaction time, initial concentration, and final concentration of $\mathrm{NH}_{4}{ }^{+}-\mathrm{N}\left(\mathrm{NO}_{3}{ }^{-}-\mathrm{N}_{\text {or }} \mathrm{NO}_{2}{ }^{-}-\mathrm{N}\right)$ during the corresponding period, respectively.

\subsection{Analytical Methods}

All the methods use a spectrophotometer (UV1000, Techcomp Limited, Shanghai, China). The cell density was assayed $\mathrm{OD}_{600}$ at a wavelength of $600 \mathrm{~nm}$. TN or biomass nitrogen concentration was analyzed using alkaline potassium persulfate digestion and the corresponding absorbance value was calculated by the equation: $A=A_{220}-2 A_{275}\left(\mathrm{~A}_{220} / \mathrm{A}_{275}\right.$ means the absorbance value at $\left.220 / 275 \mathrm{~nm}\right)$ to eliminate background interference. The concentrations of $\mathrm{NH}_{4}{ }^{+}-\mathrm{N}, \mathrm{NO}_{3}{ }^{-}-\mathrm{N}, \mathrm{NO}_{2}{ }^{-}-\mathrm{N}$, and $\mathrm{NH}_{2} \mathrm{OH}-\mathrm{N}$ were analyzed using the supernatant with different methods. $\mathrm{NH}_{4}{ }^{+}-\mathrm{N}$ concentration was determined using indophenol blue colorimetry. $\mathrm{NO}_{3}{ }^{-} \mathrm{N}$ concentration was calculated by the absorbance value at $220 \mathrm{~nm}$, subtracting the two times background absorbance value at $275 \mathrm{~nm} . \mathrm{NO}_{2}{ }^{-}-\mathrm{N}$ concentration was determined at a wavelength of $540 \mathrm{~nm}$ after adding $1 \mathrm{~mL}$ of chromogenic reagent including (per liter) $100 \mathrm{~mL}$ phosphoric acid, $2 \mathrm{~g} N$-(1-naphthyl)-1,2-diaminoethane dihydrochloride, and sulfanilamide. $\mathrm{NH}_{2} \mathrm{OH}-\mathrm{N}$ concentration was analyzed by coupling reaction spectrophotometry. Statistical analysis and graphic plotting were conducted by using SPSS Statistic, Excel, and Origin 8.6. For each kind of medium, the results are presented as means $\pm \mathrm{SD}$ (standard deviation of means).

\section{Results}

\subsection{Heterotrophic Nitrification Performance of Strain Y-12}

Figure 1 depicts the heterotrophic nitrification performance of strain $\mathrm{Y}-12$ at $15^{\circ} \mathrm{C}$ in $\mathrm{NM}$. During the logarithmic phase (from 0 to $48 \mathrm{~h}$ ), $\mathrm{OD}_{600}$ increased from 0.11 to 1.68 without lag phase, and approximately $77.4 \%$ of the initial $\mathrm{NH}_{4}{ }^{+}-\mathrm{N}$ was removed sharply. After 4 days of cultivation, the concentration of $\mathrm{NH}_{4}{ }^{+}-\mathrm{N}$ decreased from 208.1 to $2.4 \mathrm{mg} / \mathrm{L}$ with a removal ratio of $98.8 \%$, and the average nitrification rate was calculated to be $2.14 \mathrm{mg} \mathrm{NH}_{4}{ }^{+}-\mathrm{N} / \mathrm{L} / \mathrm{h}$. From 1 day to 2 days, the removal of $\mathrm{NH}_{4}{ }^{+}-\mathrm{N}$ was the fastest; $\mathrm{NH}_{4}{ }^{+}-\mathrm{N}$ decreased from 177.3 to $47.0 \mathrm{mg} / \mathrm{L}$ with a maximum nitrification rate of $5.43 \mathrm{mg} \mathrm{NH}_{4}{ }^{+}-\mathrm{N} / \mathrm{L} / \mathrm{h}$. The concentration of biomass nitrogen increased from 0.8 to $122.0 \mathrm{mg} / \mathrm{L}$. Moreover, $32.1 \%$ of TN was removed with an initial concentration of $211.6 \mathrm{mg} / \mathrm{L}$ after 4 days of incubation, which may be converted into gaseous nitrogen. During the removal process, $\mathrm{NO}_{2}{ }^{-}-\mathrm{N}$ presented with a maximum concentration of $0.1 \mathrm{mg} / \mathrm{L}$, and $\mathrm{NO}_{3}{ }^{-}-\mathrm{N}$ was detected at $5.4 \mathrm{mg} / \mathrm{L}$ but finally decreased to $1.9 \mathrm{mg} / \mathrm{L}$. Strain Y-12 showed efficient capability of $\mathrm{NH}_{4}{ }^{+}-\mathrm{N}$ removal with less accumulation of $\mathrm{NO}_{2}{ }^{-}-\mathrm{N}$ and $\mathrm{NO}_{3}{ }^{-}-\mathrm{N}$ under low temperature and aerobic conditions. 


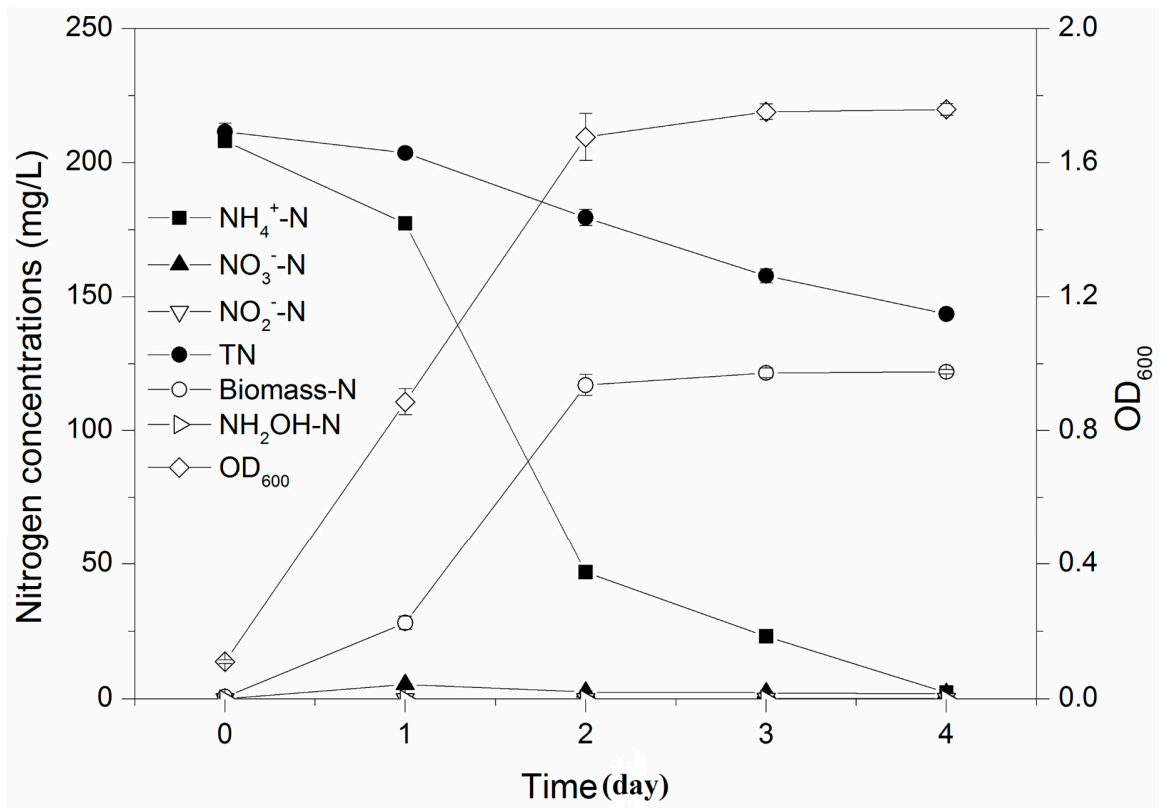

Figure 1. Heterotrophic nitrification characteristics of strain Y-12 in the presence of $\mathrm{NH}_{4}{ }^{+}-\mathrm{N}$.

\subsection{Aerobic Denitrification Performance of Strain Y-12}

Figures 2 and 3 show the aerobic denitrification performance and cell growth of strain Y-12 in DM-1 and DM-2, separately. In both DM-1 and DM-2, $\mathrm{OD}_{600}$ presents a trend of earlier increase and later decrease. $\mathrm{OD}_{600}$ increased from 0.15 at 0 day to 0.56 at 1 day when adding $\mathrm{NO}_{3}{ }^{-} \mathrm{N}$ as a sole nitrogen source (Figure 2) and increased from 0.15 at 0 day to 0.32 at 1 day when adding $\mathrm{NO}_{2}{ }^{-}-\mathrm{N}$ solely (Figure 3). And an obvious lag phase is shown in Figure 2. Although $\mathrm{NO}_{2}{ }^{-}-\mathrm{N}$ showed more inhibition than $\mathrm{NO}_{3}{ }^{-}-\mathrm{N}$, a similar growth rate and cell yield of strain $\mathrm{Y}-12$ were obtained. After 4 days of cultivation, in DM-1 (as shown in Figure 2), the concentration of $\mathrm{NO}_{3}{ }^{-}-\mathrm{N}$ significantly decreased from 204.7 to $54.0 \mathrm{mg} / \mathrm{L}$ with a removal ratio of $73.6 \%$, and about $208.5 \mathrm{mg} / \mathrm{L}$ of TN decreased to $134.3 \mathrm{mg} / \mathrm{L}$. In DM-2 (as shown in Figure 3), 77.1\% of initial $\mathrm{NO}_{2}{ }^{-}-\mathrm{N}$ was removed with an initial concentration of $199.0 \mathrm{mg} / \mathrm{L}$, and about $214.8 \mathrm{mg} / \mathrm{L}$ of TN was reduced to $132.2 \mathrm{mg} / \mathrm{L}$. The average denitrification rates of $\mathrm{NO}_{3}{ }^{-}-\mathrm{N}$ and $\mathrm{NO}_{2}{ }^{-}-\mathrm{N}$ were calculated to be $1.57 \mathrm{mg} \mathrm{NO}_{3}{ }^{-} \mathrm{N} / \mathrm{L} / \mathrm{h}$ and $1.60 \mathrm{mg} \mathrm{NO}{ }^{-}-\mathrm{N} / \mathrm{L} / \mathrm{h}$ at $15^{\circ} \mathrm{C}$, respectively. And the fastest removal of $\mathrm{NO}_{3}{ }^{-}-\mathrm{N}$ or $\mathrm{NO}_{2}{ }^{-}-\mathrm{N}$ occurred between 1 day and 2 days, and the corresponding maximum denitrification rate was 3.28 $\mathrm{mg} \mathrm{NO}{ }_{3}^{-}-\mathrm{N} / \mathrm{L} / \mathrm{h}$ in DM-1 or $3.25 \mathrm{mg} \mathrm{NO}_{2}{ }^{-} \mathrm{N} / \mathrm{L} / \mathrm{h}$ in DM-2. Meanwhile, intermediate products $\left(\mathrm{NO}_{2}{ }^{-}-\mathrm{N}\right.$ or $\left.\mathrm{NO}_{3}{ }^{-}-\mathrm{N}\right)$ accumulated at a low level during the aerobic denitrification process, $\mathrm{NO}_{2}{ }^{-}-\mathrm{N}$ accumulated with a maximum concentration of $4.8 \mathrm{mg} / \mathrm{L}$ at 2 days and reduced to $0.5 \mathrm{mg} / \mathrm{L}$ at 4 days in DM-1, and $\mathrm{NO}_{3}{ }^{-}-\mathrm{N}$ accumulated with a maximum concentration of $4.2 \mathrm{mg} / \mathrm{L}$ at 2 days and decreased to $1.6 \mathrm{mg} / \mathrm{L}$ finally in DM-2. The concentration of biomass nitrogen increased from 0.9 to $101.5 \mathrm{mg} / \mathrm{L}$ and decreased to $91.3 \mathrm{mg} / \mathrm{L}$ at 4 days in DM-1, and in DM-2 it increased from 0.9 to $97.3 \mathrm{mg} / \mathrm{L}$ and finally decreased to $90.0 \mathrm{mg} / \mathrm{L}$. The maximum biomass nitrogen obtained in DM-1 was higher than that in DM-2, although a similar growth rate and cell yield were obtained, which might be attributed to the higher toxicity of $\mathrm{NO}_{2}{ }^{-}-\mathrm{N}$. 


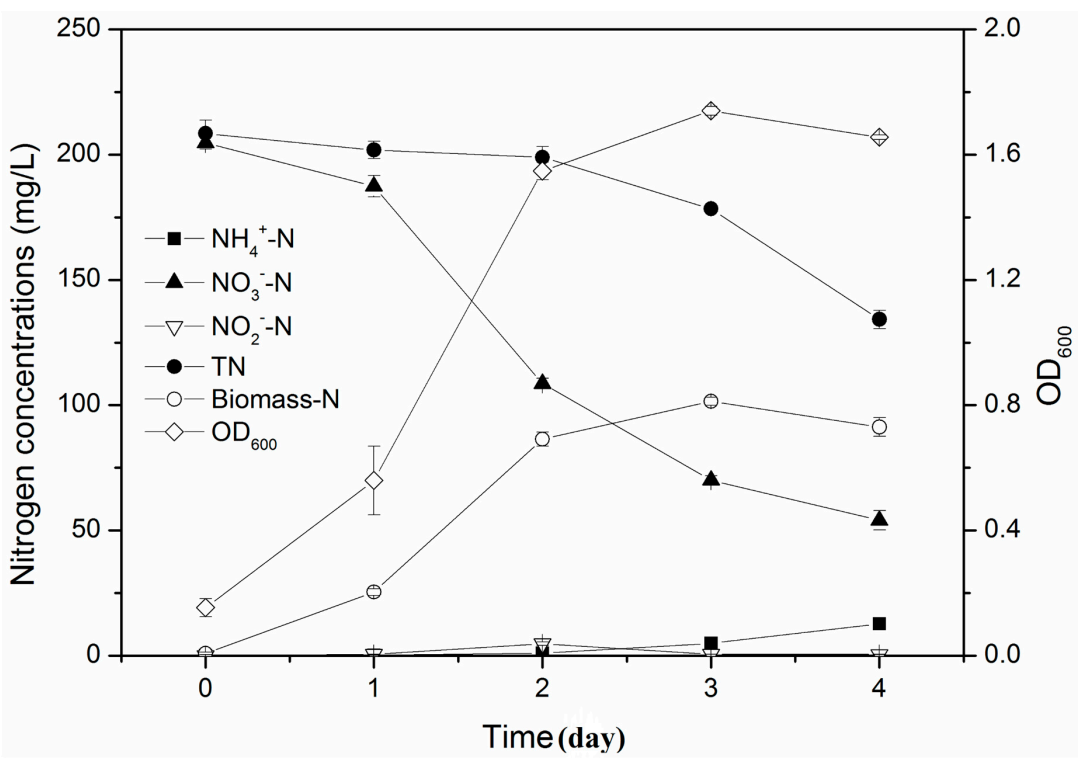

Figure 2. Aerobic denitrification characteristics of strain $\mathrm{Y}-12$ in the presence of $\mathrm{NO}_{3}{ }^{-}-\mathrm{N}$.

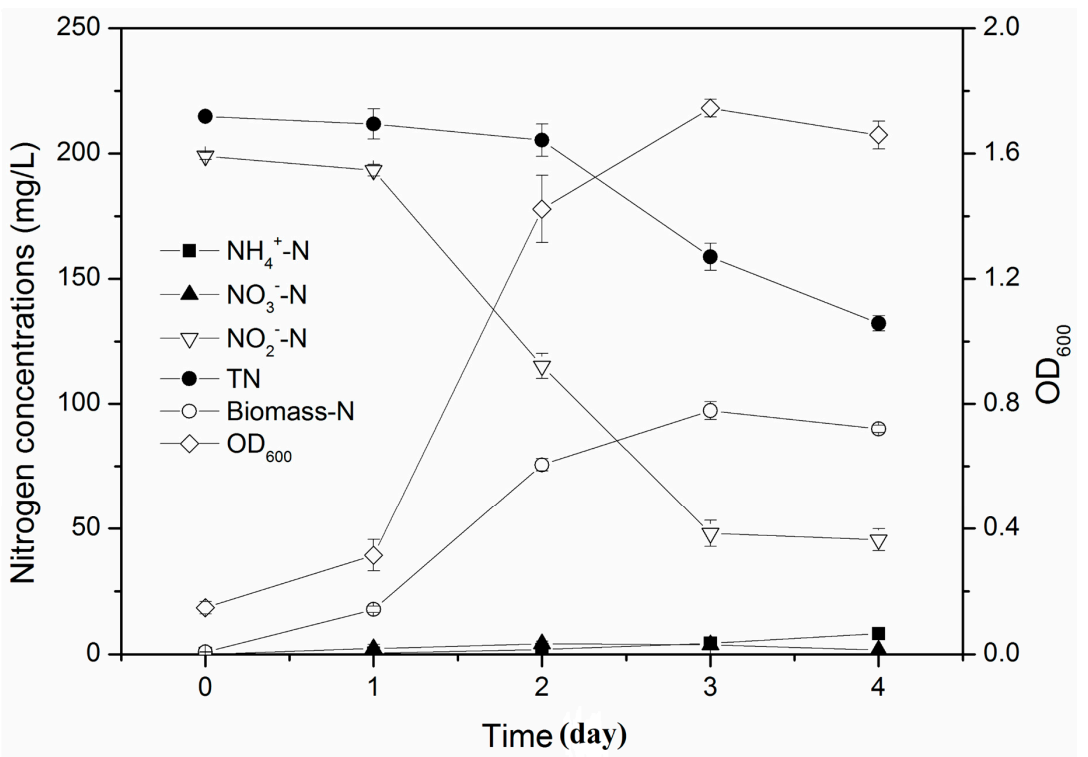

Figure 3. Aerobic denitrification characteristics of strain $\mathrm{Y}-12$ in the presence of $\mathrm{NO}_{2}{ }^{-}-\mathrm{N}$.

\subsection{Simultaneous Nitrification and Denitrification Performance in Mixed Nitrogen Sources}

To further investigate the simultaneous nitrification and denitrification performance of strain Y-12 at $15{ }^{\circ} \mathrm{C}$, two nitrogen sources were added to SND-1 and SND-2. As Figure 4 illustrates, when $\mathrm{NH}_{4}{ }^{+}-\mathrm{N}$ and $\mathrm{NO}_{3}{ }^{-}-\mathrm{N}$ coexisted, $\mathrm{OD}_{600}$ increased from 0.21 to 1.80 without an apparent lag phase in SND-1, exhibiting a higher cell yield than that for $\mathrm{NH}_{4}{ }^{+}-\mathrm{N}$ or $\mathrm{NO}_{3}{ }^{-}-\mathrm{N}$ solely. After 4 days of cultivation, $\mathrm{NH}_{4}{ }^{+}-\mathrm{N}$ significantly reduced from 201.8 to $1.1 \mathrm{mg} / \mathrm{L}$ with a removal rate of $2.07 \mathrm{mg}$ $\mathrm{NH}_{4}{ }^{+}-\mathrm{N} / \mathrm{L} / \mathrm{h}$, which was not inhibited by added $\mathrm{NO}_{3}{ }^{-}-\mathrm{N}$. The concentration of $\mathrm{TN}$ decreased from 418.2 to $355.1 \mathrm{mg} / \mathrm{L}$, and almost $15.1 \%$ of TN was denitrified in SND-1. Meanwhile, $\mathrm{NO}_{2}{ }^{-}-\mathrm{N}$ accumulated with a maximum concentration of $2.3 \mathrm{mg} / \mathrm{L}$ at 3 days and ultimately decreased to $1.6 \mathrm{mg} / \mathrm{L}$. Biomass nitrogen increased from 1.0 to $137.8 \mathrm{mg} / \mathrm{L}$ and then decreased to $135.2 \mathrm{mg} / \mathrm{L}$. Strain Y-12 could efficiently remove $\mathrm{NH}_{4}{ }^{+}-\mathrm{N}$ in the presence of $\mathrm{NO}_{3}{ }^{-}-\mathrm{N}$ at low temperatures. 


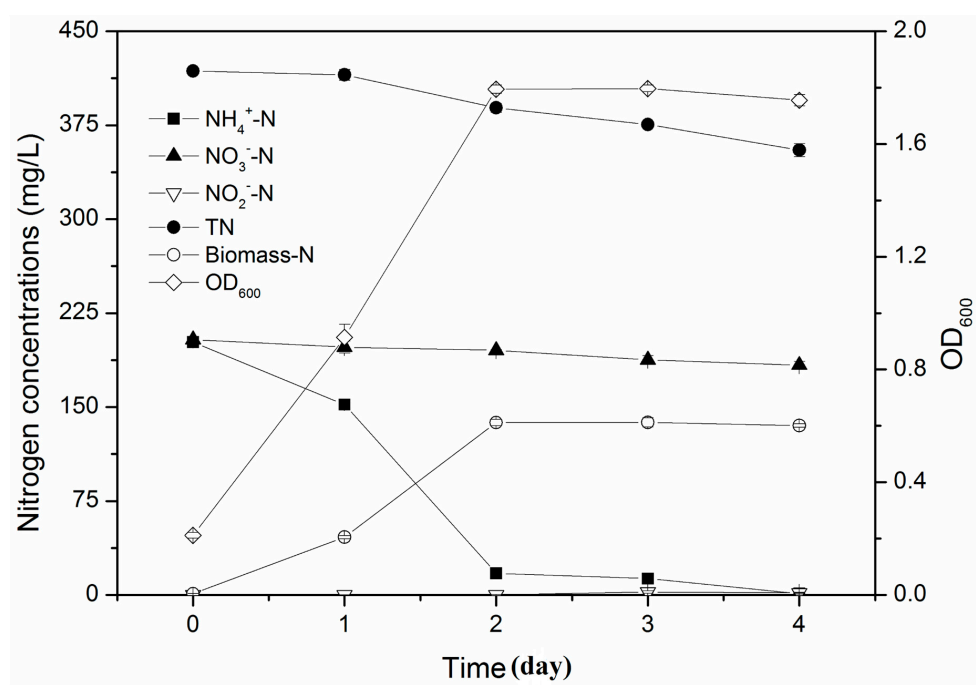

Figure 4. Simultaneous nitrification and denitrification characteristics of strain $\mathrm{Y}-12$ in the presence of $\mathrm{NH}_{4}{ }^{+}-\mathrm{N}$ and $\mathrm{NO}_{3}{ }^{-}-\mathrm{N}$.

Figure 5 shows the cell growth and nitrogen removal performance of strain Y-12 in SND-2 when $\mathrm{NH}_{4}{ }^{+}-\mathrm{N}$ and $\mathrm{NO}_{2}{ }^{-}-\mathrm{N}$ coexisted. $\mathrm{OD}_{600}$ increased slowly in the first three days with lag phase, which may be attributed to the greater toxicity of $\mathrm{NO}_{2}{ }^{-}-\mathrm{N}$ than $\mathrm{NO}_{3}{ }^{-}-\mathrm{N}$ under the same conditions. The high concentration of TN might be another reason. After adapting to high-loading nitrogen, cells grew quickly, and $\mathrm{OD}_{600}$ increased to 1.56 at 4 days. After 4 days of incubation, $\mathrm{NH}_{4}{ }^{+}-\mathrm{N}$ gradually lowered from 202.1 to $58.0 \mathrm{mg} / \mathrm{L}$ with a removal rate of $1.50 \mathrm{mg} \mathrm{NH}_{4}{ }^{+} \mathrm{N} / \mathrm{L} / \mathrm{h}$, and only $3.9 \%$ of $\mathrm{NO}_{2}{ }^{-}-\mathrm{N}$ was removed with an initial concentration of $201.7 \mathrm{mg} / \mathrm{L}$. The removal ratio of $\mathrm{NH}_{4}{ }^{+}-\mathrm{N}$ in SND-2 (71.3\%) was lower than that in SND-1 (99.5\%), demonstrating that the added $\mathrm{NO}_{2}{ }^{-}-\mathrm{N}$ had negative effects on the $\mathrm{NH}_{4}{ }^{+}$-N removal under high-loading nitrogen conditions. The concentration of TN decreased from 405.5 to $381.4 \mathrm{mg} / \mathrm{L}$. The concentration of biomass nitrogen increased from 0.9 to $115.1 \mathrm{mg} / \mathrm{L}$ in the period from 0 to 4 days. At 4 days, strain Y-12 was still in the log phase. However, the removal of TN occurred mainly during the stationary phase. Therefore, the removal of TN may be improved by extending the reaction time. Also, $\mathrm{NO}_{3}{ }^{-}-\mathrm{N}$ accumulated at $2.3 \mathrm{mg} / \mathrm{L}$. Strain $\mathrm{Y}-12$ could efficiently remove $\mathrm{NH}_{4}{ }^{+}-\mathrm{N}$ in the presence of other nitrogen sources that coexisted at low temperatures.

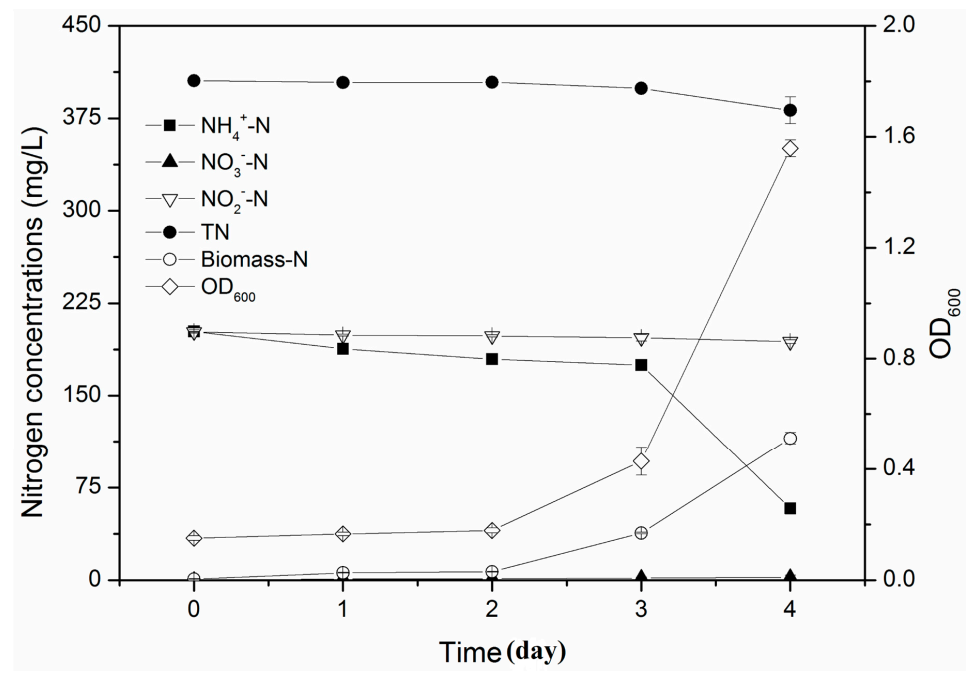

Figure 5. Simultaneous nitrification and denitrification characteristics of strain $\mathrm{Y}-12$ in the presence of $\mathrm{NH}_{4}{ }^{+}-\mathrm{N}$ and $\mathrm{NO}_{2}{ }^{-}-\mathrm{N}$. 


\section{Discussion}

When a sole nitrogen source was added, strain $\mathrm{Y}-12$ could remove $\mathrm{NH}_{4}{ }^{+}-\mathrm{N}, \mathrm{NO}_{3}{ }^{-}-\mathrm{N}$, and $\mathrm{NO}_{2}{ }^{-}-\mathrm{N}$ separately, which had more advantages than other bacteria such as Alcaligenes faecalis No. 4 [14], Acinetobacter calcoaceticus HNR [12], Paracoccus versutus LYM [5], and Alcaligenes faecalis NR [15]. Alcaligenes faecalis No. 4 [14] could utilize neither $\mathrm{NO}_{3}{ }^{-}-\mathrm{N}$ nor $\mathrm{NO}_{2}{ }^{-}-\mathrm{N}$ as the nitrogen source for growth or as the energy source for denitrification, even with efficient $\mathrm{NH}_{4}{ }^{+}-\mathrm{N}$ removal ability. Acinetobacter calcoaceticus HNR [12] could not reduce $\mathrm{NO}_{2}{ }^{-}-\mathrm{N}$, even when induced by $\mathrm{NH}_{4}{ }^{+}-\mathrm{N}$. Paracoccus versutus LYM [5] could not utilize $\mathrm{NO}_{2}{ }^{-}-\mathrm{N}$ as a sole nitrogen source unless $\mathrm{NH}_{4}{ }^{+}-\mathrm{N}$ existed. Alcaligenes faecalis NR [15] was only able to oxidize $\mathrm{NO}_{2}{ }^{-}-\mathrm{N}$ to $\mathrm{NO}_{3}{ }^{-}-\mathrm{N}$ instead of denitrifying it to nitrogenous gas. These results might be ascribed to the denitrifying enzyme activity, which was not activated or lacking, and a similar result was reported in Acinetobacter calcoaceticus HNR [12]; neither periplasmic NR nor $c d 1$-type NiR activity was detected under aerobic conditions by strain HNR. Moreover, strain Y-12 showed efficient nitrification and denitrification abilities, although low temperature is a main limiting factor of nitrification and denitrification. The nitrification rate of strain Y-12 was $2.14 \mathrm{mg} \mathrm{NH}_{4}{ }^{+} \mathrm{N} / \mathrm{L} / \mathrm{h}$, which was higher than that of Pseudomonas migulae AN-1 (1.56 $\left.\mathrm{mg} \mathrm{NH}_{4}{ }^{+}-\mathrm{N} / \mathrm{L} / \mathrm{h}\right)$ at $10^{\circ} \mathrm{C}$ [17], and higher than that of Microbacterium esteraromaticum SFA13 (lower than $2 \mathrm{mg} \mathrm{NH}{ }_{4}^{+}-\mathrm{N} / \mathrm{L} / \mathrm{h}$ ) at the same temperature of $15{ }^{\circ} \mathrm{C}$ [24]. The denitrification rate of strain Y-12 was $1.57 \mathrm{mg} \mathrm{NO}_{3}{ }^{-} \mathrm{N} / \mathrm{L} / \mathrm{h}$ or $1.60 \mathrm{mg} \mathrm{NO}_{2}{ }^{-}-\mathrm{N} / \mathrm{L} / \mathrm{h}$ at $15^{\circ} \mathrm{C}$, which was higher than that of these bacteria under higher temperature conditions. These bacteria were Pseudomonas migulae AN-1 (1.57 $\mathrm{mg} \mathrm{NO}{ }^{-}-\mathrm{N} / \mathrm{L} / \mathrm{h}$ or $\left.0.69 \mathrm{mg} \mathrm{NO}{ }^{-}-\mathrm{N} / \mathrm{L} / \mathrm{h}, 30^{\circ} \mathrm{C}\right)$ [17], Rhodococcus sp. CPZ24 (0.93 mg $\mathrm{NO}_{3}{ }^{-}-\mathrm{N} / \mathrm{L} / \mathrm{h}, 30{ }^{\circ} \mathrm{C}$ ) [25], Bacillus methylotrophicus L7 (5.81 $\mathrm{mg} \mathrm{NO}_{2}{ }^{-}-\mathrm{N} / \mathrm{L} / \mathrm{d}, 37{ }^{\circ} \mathrm{C}$ ) [25], and Pseudomonas sp. yy7 (18.2 $\left.\mathrm{mg} \mathrm{NO}_{2}{ }^{-}-\mathrm{N} / \mathrm{L} / \mathrm{d}, 25^{\circ} \mathrm{C}\right)$ [11]. Besides, $\mathrm{TN}$ was removed from water mainly during the stationary phase of strain $\mathrm{Y}-12$ in the denitrification process. In Figure 2, almost $9.5 \mathrm{mg} / \mathrm{L} \mathrm{TN}$ was removed during the logarithmic phase, while $64.7 \mathrm{mg} / \mathrm{L}$ of TN was removed during the stationary phase. In Figure 3, the removed TN amounted to 7.8 and $73.1 \mathrm{mg} / \mathrm{L}$ during the logarithmic phase and stationary phase, respectively.

When removing mixed nitrogen sources, the removal ratios of $\mathrm{NH}_{4}{ }^{+}-\mathrm{N}$ and $\mathrm{NO}_{3}{ }^{-}-\mathrm{N}$ were $99.5 \%$ and $10.0 \%$ in SND-1, the removal ratios of $\mathrm{NH}_{4}{ }^{+}-\mathrm{N}^{-}$and $\mathrm{NO}_{2}{ }^{-}-\mathrm{N}$ were $71.3 \%$ and $3.9 \%$ in SND-2, and the removed TN was $63.1 \mathrm{mg} / \mathrm{L}$ in SND-1 and $24.1 \mathrm{mg} / \mathrm{L}$ in SND-2, which might be attributed to: (1) the different enzyme activities; (2) less reaction time after bacteria adapted to the high concentration of $\mathrm{NO}_{2}{ }^{-}-\mathrm{N}$; and (3) more inhibition of $\mathrm{NO}_{2}{ }^{-}-\mathrm{N}$ in bacteria. Although the utilization of $\mathrm{NH}_{4}{ }^{+}-\mathrm{N}$ was much more than $\mathrm{NO}_{3}{ }^{-}-\mathrm{N}$ or $\mathrm{NO}_{2}{ }^{-}-\mathrm{N}, \mathrm{NH}_{4}{ }^{+}-\mathrm{N}$ coexisting with $\mathrm{NO}_{3}{ }^{-}-\mathrm{N} / \mathrm{NO}_{2}{ }^{-}-\mathrm{N}$ could be utilized simultaneously by strain Y-12. Different phenomena were showed in Pseudomonas mendocina 3-7 [2]; for example, strain 3-7 completely utilized $\mathrm{NH}_{4}{ }^{+}-\mathrm{N}$ first as a nitrogen source for microbial metabolism before $\mathrm{NO}_{3}{ }^{-}-\mathrm{N}$. Also, the removal of $\mathrm{NO}_{3}{ }^{-}-\mathrm{N}$ or $\mathrm{NO}_{2}{ }^{-}-\mathrm{N}$ might be related to the carbon source. When a sole nitrogen source was added, the $\mathrm{C} / \mathrm{N}$ ratio was approximately 14 , and when two nitrogen sources existed, the $\mathrm{C} / \mathrm{N}$ ratio was approximately 7 . The reason for the low removal of $\mathrm{NO}_{3}{ }^{-}-\mathrm{N}$ or $\mathrm{NO}_{2}{ }^{-}-\mathrm{N}$ might be the insufficient carbon concentration after the removal of $\mathrm{NH}_{4}{ }^{+}-\mathrm{N}$, and the removal ratio might be improved by adding carbon sources. Even though the removal of $\mathrm{NO}_{3}{ }^{-}-\mathrm{N}$ or $\mathrm{NO}_{2}{ }^{-}-\mathrm{N}$ was at a low level, strain Y-12 could conduct simultaneous nitrification and denitrification under aerobic conditions at low temperatures, showing more advantages than Acinetobacter calcoaceticus HNR [12].

In practical applications, the accumulation of intermediate products would reduce the nitrogen removal efficiency and might cause secondary pollution to the environment. $\mathrm{NH}_{2} \mathrm{OH}-\mathrm{N}$ is always thought to be the intermediate of nitrification. Although $\mathrm{NH}_{2} \mathrm{OH}-\mathrm{N}$ was not detected in Figures 1, 4 and 5, it did not mean that $\mathrm{NH}_{2} \mathrm{OH}-\mathrm{N}$ was not produced; the produced $\mathrm{NH}_{2} \mathrm{OH}-\mathrm{N}$ might be converted too quickly to be detected. In all experiments, $\mathrm{NO}_{3}{ }^{-}-\mathrm{N}$ and/or $\mathrm{NO}_{2}{ }^{-}-\mathrm{N}$ were/was detected at low levels. When removing $\mathrm{NH}_{4}{ }^{+}-\mathrm{N}$ solely, $\mathrm{NO}_{2}{ }^{-}-\mathrm{N}$ was presented with a maximum concentration of $0.1 \mathrm{mg} / \mathrm{L}$, and $\mathrm{NO}_{3}{ }^{-}-\mathrm{N}$ was detected at $5.4 \mathrm{mg} / \mathrm{L}$ but finally decreased to $1.9 \mathrm{mg} / \mathrm{L}$, exhibiting that strain $\mathrm{Y}-12$ had more advantages than bacteria with greater accumulation of $\mathrm{NO}_{3}{ }^{-}-\mathrm{N}$ and $\mathrm{NO}_{2}{ }^{-}-\mathrm{N}[15,26,27]$. When removing $\mathrm{NO}_{3}{ }^{-}-\mathrm{N}$ or $\mathrm{NO}_{2}{ }^{-} \mathrm{N}$, the accumulation of $\mathrm{NO}_{2}{ }^{-}-\mathrm{N}$ or $\mathrm{NO}_{3}{ }^{-}-\mathrm{N}$, especially for 
harmful $\mathrm{NO}_{2}{ }^{-}-\mathrm{N}$, was far less than that of P. denitrificans or P. Fluorescens [6] at the same temperature of $15{ }^{\circ} \mathrm{C}$. When removing mixed nitrogen sources, $1.6 \mathrm{mg} / \mathrm{L}$ of $\mathrm{NO}_{2}{ }^{-}-\mathrm{N}$ was detected in SND-1 and $2.3 \mathrm{mg} / \mathrm{L}$ of $\mathrm{NO}_{3}{ }^{-}-\mathrm{N}$ was detected in SND-2 at 4 days. Furthermore, some accumulation of $\mathrm{NH}_{4}{ }^{+}-\mathrm{N}(12.7 \mathrm{mg} / \mathrm{L}$ in DM-1 and $8.21 \mathrm{mg} / \mathrm{L}$ in DM-2) detected at 4 days might be attributed to the decomposition of the death cells, as reported in previous studies [9]. According to the detected $\mathrm{NO}_{3}{ }^{-}-\mathrm{N}$ and $\mathrm{NO}_{2}{ }^{-}-\mathrm{N}$ in $\mathrm{NM}$, strain Y-12 possibly conducted heterotrophic nitrification through the sequence of $\mathrm{NH}_{4}{ }^{+} \rightarrow\left(\mathrm{NH}_{2} \mathrm{OH} \rightarrow\right) \mathrm{NO}_{2}{ }^{-} \rightarrow \mathrm{NO}_{3}{ }^{-}$, and a similar result was reported by Hu et al. [28]. In DM-1 and DM-2, $\mathrm{NO}_{2}{ }^{-}-\mathrm{N}$ and $\mathrm{NO}_{3}{ }^{-}-\mathrm{N}$ were slightly accumulated, and the aerobic denitrification process might have been conducted through $\mathrm{NO}_{3}{ }^{-} \rightarrow \mathrm{NO}_{2}{ }^{-} \rightarrow \mathrm{NO} \rightarrow \mathrm{N}_{2} \mathrm{O} \rightarrow \mathrm{N}_{2}$, as reported in previous studies $[7,8]$.

Furthermore, the assimilation was also conducted by strain $\mathrm{Y}-12$ to support the cell growth. In Figures 1-3, the cell yield was similar and the maximum $\mathrm{OD}_{600}$ was around 1.75. Although similar cell yield was obtained, the accumulated biomass nitrogen showed differences, which might be ascribed to different species of nitrogen sources. In the simultaneous nitrification and denitrification process, shown in Figure 4, the cell yield was higher than sole addition of $\mathrm{NH}_{4}{ }^{+}-\mathrm{N}$ or $\mathrm{NO}_{3}{ }^{-}-\mathrm{N}$. This might be because the total addition of nitrogen was much higher in the simultaneous nitrification and denitrification process. In Figure 5, the $\mathrm{OD}_{600}$ was lower and was only 1.56 at 4 days, which might be ascribed to the long-time adaptive phase and might be improved by extending the reaction time. Strain Y-12 could quickly decrease the high concentration of $\mathrm{NH}_{4}{ }^{+}-\mathrm{N}, \mathrm{NO}_{3}{ }^{-}-\mathrm{N}$, or $\mathrm{NO}_{2}{ }^{-}-\mathrm{N}$ contained in water bodies at low temperatures, which was beneficial to improve the self-purification capacity of water bodies. Moreover, $\mathrm{NH}_{4}{ }^{+}-\mathrm{N}$ was also removed in the presence of other nitrogen sources at low temperatures. The removal performance might be improved by the addition of a carbon source, the combination of strains with different nitrogen removal performances, and the extension of the reaction time.

\section{Conclusions}

Strain $\mathrm{Y}-12$ showed abilities to remove sole and mixed nitrogen. When removing sole nitrogen, strain Y-12 presented a maximum nitrification rate of $5.43 \mathrm{mg} \mathrm{NH}_{4}{ }^{+}-\mathrm{N} / \mathrm{L} / \mathrm{h}$ and a denitrification rate of $3.28 \mathrm{mg} \mathrm{NO}_{3}{ }^{-}-\mathrm{N} / \mathrm{L} / \mathrm{h}$ or $3.25 \mathrm{mg} \mathrm{NO}_{2}{ }^{-}-\mathrm{N} / \mathrm{L} / \mathrm{h}$ during 4 days of incubation. When two nitrogen sources coexisted, $\mathrm{NH}_{4}{ }^{+}-\mathrm{N}$ was also removed in the presence of other nitrogen sources at low temperatures. Intermediate products $\left(\mathrm{NO}_{3}{ }^{-}-\mathrm{N}\right.$ and $\left.\mathrm{NO}_{2}{ }^{-}-\mathrm{N}\right)$ were accumulated at low levels. Besides the nitrogen converted into gaseous nitrogen out of water bodies, most of the decreased $\mathrm{NH}_{4}{ }^{+}-\mathrm{N}, \mathrm{NO}_{3}{ }^{-}-\mathrm{N}$, or $\mathrm{NO}_{2}{ }^{-}-\mathrm{N}$ was utilized to support cell growth. The nitrogen removal rate could be improved by increasing the incubation time when $\mathrm{NH}_{4}{ }^{+}-\mathrm{N}$ and $\mathrm{NO}_{2}{ }^{-}-\mathrm{N}$ coexisted. All the results showed that strain Y-12 was capable of heterotrophic nitrification and aerobic denitrification solely and simultaneously at low temperatures.

Acknowledgments: This work was supported by the National Key Research and Developmental Program of China (2017YFC0404700).

Author Contributions: Q.Y., and T.H. conceived and designed the experiments; Q.Y., K.L., Y.X., W.T., and S.X. carried out the experiments; Q.Y. and K.L. analyzed the data; Q.Y. and Z.L. wrote the main manuscript text and all authors reviewed the manuscript.

Conflicts of Interest: The authors declare no conflict of interest.

\section{References}

1. Adav, S.S.; Lee, D.J.; Lai, J.Y. Enhanced biological denitrification of high concentration of nitrite with supplementary carbon source. Appl. Microbiol. Biotechnol. 2010, 85, 773-778. [CrossRef] [PubMed]

2. Zhu, L.; Ding, W.; Feng, L.-J.; Dai, X.; Xu, X.-Y. Characteristics of an aerobic denitrifier that utilizes ammonium and nitrate simultaneously under the oligotrophic niche. Environ. Sci. Pollut. Res. 2012, 19, 3185-3191. [CrossRef] [PubMed]

3. Desireddy, S.; Sabumon, P.-C.; Maliyekkal, S.-M. Microbial mediated anoxic nitrification-denitrification in the presence of nanoscale oxides of manganese. Int. Biodeterior. Biodegrad. 2017, 117, 499-510. 
4. Shao, Y.-X.; Shi, Y.-J.; Mohammed, A.; Liu, Y. Wastewater ammonia removal using an integrated fixed-film activated sludge-sequencing batch biofilm reactor (IFAS-SBR): Comparison of suspended flocs and attached biofilm. Int. Biodeterior. Biodegrad. 2017, 116, 38-41. [CrossRef]

5. Zhang, S.-M.; Sha, C.-Q.; Jiang, W.; Li, W.-G.; Zhang, D.-Y.; Li, J.; Meng, L.-Q.; Piao, Y.-J. Ammonium removal at low temperature by a newly isolated heterotrophic nitrifying and aerobic denitrifying bacterium Pseudomonas fluorescens wsw-1001. Environ. Technol. 2015, 36, 2488-2494. [CrossRef] [PubMed]

6. Vacková, L.; Srb, M.; Stloukal, R.; Wanner, J. Comparison of denitrification at low temperature using encapsulated Paracoccus denitrificans, Pseudomonas fluorescens and mixed culture. Bioresour. Technol. 2011, 102, 4661-4666. [CrossRef] [PubMed]

7. Khardenavis, A.A.; Kapley, A.; Purohit, H.J. Simultaneous nitrification and denitrificationby diverse Diaphorobacter sp. Appl. Microbiol. Biotechnol. 2007, 77, 403-409. [CrossRef] [PubMed]

8. Khin, T.; Annachhatre, A.P. Novel microbial nitrogen removal processes. Biotechnol. Adv. 2004, 22, 519-532. [CrossRef] [PubMed]

9. He, T.-X.; Li, Z.-L.; Sun, Q.; Xu, Y.; Ye, Q. Heterotrophic nitrification and aerobic denitrification by Pseudomonas tolaasii Y-11 without nitrite accumulation during nitrogen conversion. Bioresour. Technol. 2016, 200, 493-499. [CrossRef] [PubMed]

10. Lesley, A.; Robertson, J.G.K. Combined heterotrophic nitrification and aerobic denitrification in Thiosphaera pantotropha and other bacteria. Antonie Van Leeuwenhoek 1989, 57, 139-152.

11. Wan, C.I.; Yang, X.; Lee, D.-J.; Du, M.A.; Wan, F.; Chen, C. Aerobic denitrification by novel isolated strain using $\mathrm{NO}_{2}{ }^{-}-\mathrm{N}$ as nitrogen source. Bioresour. Technol. 2011, 102, 7244-7248. [CrossRef] [PubMed]

12. Zhao, B.; He, Y.-L.; Hughes, J.; Zhang, X.-F. Heterotrophic nitrogen removal by a newly isolated Acinetobacter calcoaceticus HNR. Bioresour. Technol. 2010, 101, 5194-5200. [CrossRef] [PubMed]

13. Shoda, M.; Ishikawa, Y. Heterotrophic nitrification and aerobic denitrification of high-strength ammonium in anaerobically digested sludge by Alcaligenes faecalis strain No. 4. J. Biosci. Bioeng. 2014, 117, 737-741. [CrossRef] [PubMed]

14. Joo, H.S.; Hirai, M.; Shoda, M. Characteristics of ammonium removal by heterotrophic nitrification-aerobic denitrification by Alcaligenes faecalis No. 4. J. Biosci. Bioeng. 2005, 100, 184-191. [CrossRef] [PubMed]

15. Zhao, B.; An, Q.; He, Y.-L.; Guo, J.-S. $\mathrm{N}_{2} \mathrm{O}$ and $\mathrm{N}_{2}$ production during heterotrophic nitrification by Alcaligenes faecalis strain NR. Bioresour. Technol. 2012, 116, 379-385. [CrossRef] [PubMed]

16. Liang, X.; Ren, Y.-X.; Yang, L.; Zhao, S.-Q.; Xia, Z.-H. Characteristics of nitrogen removal by a heterotrophic nitrification-aerobic denitrification bacterium YL. Environ. Sci. 2015, 36, 1749-1756.

17. Qu, D.; Wang, C.; Wang, Y.-F.; Zhou, R.; Ren, H.-J. Heterotrophic nitrification and aerobic denitrification by a novel groundwater origin cold-adapted bacterium at low temperatures. RSC Adv. 2015, 5, 5149-5157. [CrossRef]

18. Zhang, Y.; Shi, Z.; Chen, M.X.; Dong, X.Y.; Zhou, J.T. Evaluation of simultaneous nitrification and denitrification under controlled conditions by an aerobic denitrifier culture. Bioresour. Technol. 2015, 175, 602-605. [CrossRef] [PubMed]

19. Su, J.J.; Yeh, K.S.; Tseng, P.W. A Strain of Pseudomonas sp. isolated from piggery wastewater treatment systems with heterotrophic nitrification capability in Taiwan. Curr. Microbiol. 2006, 53, 77-81. [CrossRef] [PubMed]

20. Zhang, D.Y.; Li, W.G.; Huang, X.F.; Qin, W.; Liu, M. Removal of ammonium in surface water at low temperature by a newly isolated Microbacterium sp. strain SFA13. Environ. Technol. 2013, 137, 147-152. [CrossRef] [PubMed]

21. Yang, Y.L.; Huang, S.B.; Zhang, Y.Q.; Xu, F.Q. Nitrogen removal by Chelatococcus daeguensis TAD1 and its denitrification gene identification. Appl. Biochem. Biotechnol. 2014, 172, 829-839. [CrossRef] [PubMed]

22. He, T.X.; Li, Z.L. Isolation, screening and identification of the hypothermia highly efficient nitrite denitrifying bacteria. Acta Sci. Circumst. 2015, 35, 2393-2399.

23. Pal, R.R.; Khardenavis, A.A.; Purohit, H.J. Identification and monitoring of nitrification and denitrification genes in Klebsiella pneumoniae EGD-HP19-C for its ability to perform heterotrophic nitrification and aerobic denitrification. Funct. Integr. Genom. 2015, 15, 63-76. [CrossRef] [PubMed]

24. Zhang, D.Y.; Huang, X.F.; Li, W.G.; Qin, W.; Wang, P. Characteristics of heterotrophic nitrifying bacterium strain SFA13 isolated from the Songhua River. Ann. Microbiol. 2016, 66, 271-278. [CrossRef] 
25. Chen, P.Z.; Li, J.; Li, Q.X.; Wang, Y.C.; Li, S.P.; Ren, T.Z.; Wang, LG. Simultaneous heterotrophic nitrification and aerobic denitrification by bacterium Rhodococcus sp. CPZ24. Bioresour. Technol. 2012, 116, 266-270. [CrossRef] [PubMed]

26. Zhang, Q.L.; Liu, Y.; Ai, G.M.; Miao, L.L.; Zheng, H.Y.; Liu, Z.P. The characteristics of a novel heterotrophic nitrification-aerobic denitrification bacterium, Bacillus methylotrophicus strain L7. Bioresour. Technol. 2012, 108, 35-44. [CrossRef] [PubMed]

27. Taylor, S.M.; He, Y.L.; Zhao, B.; Huang, J. Heterotrophic ammonium removal characteristics of an aerobic heterotrophic nitrifying-denitrifying bacterium, Providencia rettgeri YL. J. Environ. Sci. 2009, 21, 1336-1341. [CrossRef]

28. Hu, Z.; Lee, J.W.; Chandran, K.; Kim, S.; Khanal, S.K. Nitrous oxide $\left(\mathrm{N}_{2} \mathrm{O}\right)$ emission from aquaculture: A review. Environ. Sci. Technol. 2012, 46, 6470-6480. [CrossRef] [PubMed]

(C) 2017 by the authors. Licensee MDPI, Basel, Switzerland. This article is an open access article distributed under the terms and conditions of the Creative Commons Attribution (CC BY) license (http://creativecommons.org/licenses/by/4.0/). 